\title{
THE EFFECTS OF ANTAGONISTIC BACTERIA AGAINST WHITE MOLD DISEASE AGENT [SCLEROTINIA SCLEROTIORUM (LIB.) DE BARY] IN CUCUMBER
}

\author{
BAYRAM, M. - BELGUZAR, S.* \\ Plant Protection Department, Agricultural Faculty, Tokat Gaziosmanpasa University, Tokat, \\ Turkey \\ *Corresponding author \\ e-mail: sabriye.yazici@gop.edu.tr; phone: +90-356-252-1616; fax: +90-356-252-1488 \\ (Received $13^{\text {th }}$ Sep 2020; accepted $11^{\text {th }}$ Feb 2021)
}

\begin{abstract}
This study was carried out to determine the effects of antagonistic bacteria, which were obtained from the soil rhizosphere and have the strong abilities to dissolve phosphorus and reduce nitrogen, on the white mold disease agent Sclerotinia sclerotiorum (Lib.) de Bary. In the study, ten antagonistic bacteria of the genus Pseudomonas were used. In the in vitro study, the tested antagonistic bacteria suppressed the mycelial growth of $S$. sclerotiorum by $65.49-88.25 \%$. Isolates with a high inhibition rate on mycelial growth were also effective on the viability of the sclerotia of the pathogenic fungus. Five bacterial isolates caused complete sclerotia viability loss for S. sclerotiorum. According to the result of the in vitro studies, antagonistic bacterial isolates with strong effects on the pathogenic fungus were selected and assayed in pot studies under greenhouse conditions. In pot studies, single treatments with Pseudomonas chlororaphis (R-7) and the dual treatments with Pseudomonas brassicacearum + Pseudomonas chlororaphis $(\mathrm{R}-3+\mathrm{R}-7)$ were the most effective against white mold disease. The results of this study show that these antagonistic bacteria can be used in the biological control of $S$. sclerotiorum. In addition to the in vitro and in vivo studies, it is necessary to determine the performances of antagonistic bacterial isolates, which had the highest effect on white mold disease, in greenhouses and field conditions.
\end{abstract}

Keywords: biological control, Sclerotinia sclerotiorum, Pseudomonas brassicacearum, Pseudomonas chlororaphis

\section{Introduction}

Species in Sclerotinia genus are soil-borne pathogens that cause significant losses to host plants. Sclerotinia sclerotiorum (Lib.) de Bary, causes white mold disease in field crops and vegetables all over the world especially in temperate regions (Ferreira and Boley, 2002). S. sclerotiorum is a reported host range of over 500 plant species from 75 families (Saharan and Mehta, 2008). In Turkey, white mold diseases has been reported in various proportions on lettuce (Lactuca sativa L.) in Izmir, Manisa and Aydin (Y1ldiz, 1970), on sunflower (Helianthus annus L.) in Thrace Region and Cukurova Region (Yucer, 1980; Cinar and Bicici, 1982), on cucumber (Cucumis sativus L.), tomato (Solanum lycopersicum L.) and eggplants (Solanum melongena L.) in the Eastern Mediterranean Region (Aksay et al., 1991), on cucumber in Tokat and Amasya (Onaran and Yanar, 2004), on lettuce in Canakkale (Turk and Dogu, 2004), on greenhouse tomatoes in the provinces of Hatay, Adana, Mersin and Antalya (Tok and Kurt, 2007), in the sunflower fields of the Pasinler Plain of Erzurum (Tozlu and Demirci, 2008), on cucumbers in the greenhouses of Antalya (Onaran, 2009) and on potato in Hatay province (Kurt et al., 2017).

Sclerotinia sclerotiorum produces lots of mycelia and these mycelia aggregate to form a hard, dark brown or black sclerotia, which are of different sizes and irregular 
shapes. This agent is easily recognized from this sclerotium, which is resistant to unfavorable environmental conditions. S. sclerotiorum usually attacks the roots or stem of the host that are in close proximity to the soil. Lesions develop on the stem and gradually surround the roots, and the host plant withers and dies. This fungus can cause complete rotting of seedlings, especially in humid environments (Anonymous, 2008).

This pathogen overwinters as sclerotium in soil, contaminated plant debris or as mycelia. In the spring, sclerotia germinates and forms apothecia in which asci and ascospores are produced. Ascospores are released into the air from the apothecia and infection begins when they land and germinate on host plant (Agrios, 1997). Studies have stated that the sclerotia of this fungus can survive in the soil for more than 5 years (Adams and Ayers, 1979) and that environmental conditions are important in the development of the disease.

Cultural measures, physical control, fumigation of soil and green parts are used in the management of white mold disease (Anonymous, 2008), however, difficulties are experienced in managing the disease as some varieties are susceptible to the pathogen, sclerotia of this fungal pathogen can remain viable or many years and not all of them germinate at the same time and more importantly the pathogen is becoming more resistant to currently available fungicides. Accordingly, different alternative methods to chemical control such as the use of antagonistic bacteria and plant growth promoting rhizobacteria (PGPR) are in demand. These bacteria are densely located around the soil rhizosphere of plant roots and they carry out physiochemical activities in the soil. They are in close relationship with plant roots and directly or indirectly have positive effect the development of the plants. These bacteria can be found in several genera but those in the genus Pseudomonas are highly efficacious and can multiply rapidly in the soil rhizosphere and spread to the root. In addition, by protecting the plant from stress, they promote plant root and shoot development, improve yield and protect plants against diseases (Imriz et al., 2014).

Several studies have been conducted by various researchers on the biological control of Sclerotinia sclerotiorum (Zazzerini and Tosi, 1985; Bogdanova et al., 1986; Turhan and Grossmann, 1986; Inbar et al., 1996; Aksay et al., 1991; Tuncer and Damdere, 1997; Thaning et al., 2001; Al-Masri et al., 2002; Kamensky et al., 2003; Mansour et al., 2008; El-Kafrawy, 2008; Onaran and Yanar, 2011; Tozlu and Demirci, 2011; Rostami et al., 2013; Tozlu et al., 2016; Abdeljalil et al., 2016; Helmy, 2016; Mun et al., 2019). In the search for alternatives, a number of mycoparasitic fungi grow on sclerotia (Adams, 1990) and Coniothyrium minitans was the most investigated fungi on $S$. sclerotiorum (Whipps and Gerlagh, 1992; Budge et al., 1995; McLaren et al., 1996; Whipps et al., 2008) and has become available as a commercial product for sclerotia (Gerlagh et al., 1999). Also, Gliocladium virens and Trichoderma harzianum have been reported to reduce growth of mycelium and apothecial production of $S$. sclerotiorum (Phillips, 1986; Whipps and Budge, 1990; Srinivasan et al., 2001; Mehta et al., 2012). Among the antagonistic bacteria species tested, Bacillus subtilis and Bacillus cereus have been reported to reduce germination of sclerotia and cause hyphal death (Zazzerini et al., 1987; Kamal et al., 2015; Sun et al., 2017). Similarly, it has been determined that Pseudomonas putida and $P$. fluorescens species reduce the damage caused by $S$. sclerotiorum (Expert and Digat, 1995), and that Bacillus spp. and Pseudomonas spp. prevent disease development by $75.3 \%$ (Soylu et al., 2005). Also, Serretia plymuthia was highly effective in inducing complete suppression of apothecial formation and 
strongly inhibited the germination of ascospores (Thaning et al., 2001). Under in vivo conditions, Burkholderia cepacia, and Serratia plymuthica species (Onaran and Yanar, 2011), B. subtilis, Serratia sp., and P. fluorescens (Helmy, 2016; El-Kafrawy, 2008), $P$. chlororaphis PA-23 (Savchuck, 2002) species have described to significantly reduce disease development. Studies conducted at the same time have also determined that $B$. subtilis, B. thuringiensis, B. amyloliquefaciens, Enterobacter cloacae, and $P$. fluorescens isolates positively affect plant growth (El-Kafrawy, 2008; Abdeljalil et al., 2016).

The aim of this study was to determine the effects of antagonistic bacteria isolates obtained from tomato production areas in Tokat province on Sclerotinia sclerotiorum, which causes white mold disease in cucumbers.

\section{Materials and methods}

In the study, 10 antagonistic bacterial isolates with high phosphate-reducing and nitrogen-binding properties, previously isolated from tomato production areas in Tokat province in Turkey and described with biochemical tests and MALDI-TOF technique, were used (Table 1). Sclerotinia sclerotiorum isolate used in the study was isolated from infected tissues of cucumber plant and identified using morphologically and molecular analysis (PCR).

Tests were carried out in Tokat province of Turkey in 2019. In vitro and in vivo tests were carried out as laboratory test and pot studies, respectively.

Table 1. Scientific names and codes of antagonistic bacteria used in this study

\begin{tabular}{c|c}
\hline Isolate code & Scientific name of the isolate \\
\hline R-1 & Pseudomonas kilonensis \\
R-2 & Pseudomonas monteilii \\
R-3 & Pseudomonas brassicacearum \\
R-4 & Pseudomonas thivervalensis \\
R-5 & Pseudomonas koreensis \\
R-6 & Pseudomonas thivervalensis \\
R-7 & Pseudomonas chlororaphis \\
R-8 & Pseudomonas sp. \\
R-9 & Pseudomonas sp. \\
R-10 & Pseudomonas thivervalensis \\
\hline
\end{tabular}

\section{In vitro tests}

Determination of the effects of antagonistic bacteria on the mycelial development of Sclerotinia sclerotiorum

Tryptic soy agar (TSA) was used throughout this study. The antagonistic bacterial isolates grown TSA for $24 \mathrm{~h}$ were inoculated in a ring form on the edges of the medium in $90 \mathrm{~mm}$ diameter petri dishes. Then, a $5 \mathrm{~mm}$ diameter mycelium disc was taken from S. sclerotiorum culture and placed in the center of the medium (Fig. 1). In the control group, only the pathogen fungus was plated onto the medium without bacteria. Petri dishes were wrapped with Parafilm and left to incubation at $25^{\circ} \mathrm{C}$. The 
experiments were ended when the fungus in the control group completely covered the petri dish and the radial growth of fungi in the control group and petri dishes treated with antagonist bacteria were measured (Tozlu et al., 2016; Kotan, 2017). Inhibition rates $(\%)$ were calculated by comparing the measured mycelium diameters. The experiment was repeated twice with five replicates per treatment (Aeron et al., 2011).

$$
\mathrm{I}(\%)=\left[(\mathrm{C}-\mathrm{T}) /\left(\mathrm{C}-\mathrm{C}_{0}\right)\right] \times 100
$$

I: inhibition rate (\%); C: mycelial diameter of the pathogen in control; T: mycelial diameter of the pathogen in bacterial treatment; $\mathrm{C}_{0}$ : the diameter of the test fungus agar $\operatorname{discs}(5 \mathrm{~mm})$.

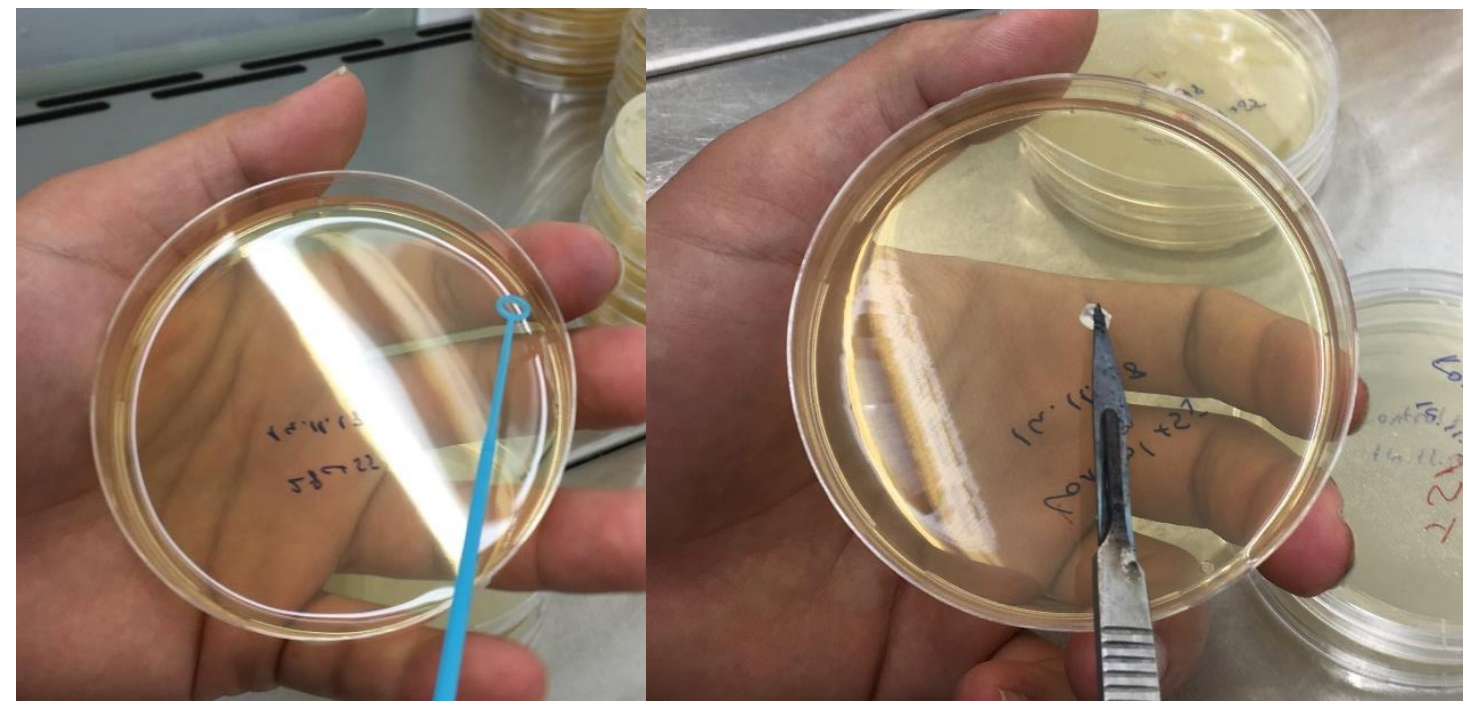

Figure 1. Inoculation of antagonistic bacteria in a ring form on the edges of the mediumposition of mycelium disc from $S$. sclerotiorum culture in the center of the medium

Determination of the effects of antagonistic bacteria on germination of Sclerotinia sclerotiorum sclerotia

First the sclerotia of S. sclerotiorum, which were developed on Potato Dextrose Agar (PDA) medium for 10 days, were subjected to surface sterilization by immersing in $2 \%$ sodium hypochlorite and passing through sterile distilled water three times. The surfacesterilized sclerotia were placed in bacterial suspensions with $10^{8}$ cells $/ \mathrm{ml}$ density prepared with $10 \mathrm{ml}$ of Luria Bertani Broth (LB) medium. Five sclerotia were used for each antagonistic bacteria isolate, and the treated erlenmeyers were incubated in a rotary incubator at $175 \mathrm{rpm}$ for $24 \mathrm{~h}$. The sclerotia treated with antagonistic bacteria were dissected into two with a scalpel and transferred to the PDA medium and left to incubate at $25^{\circ} \mathrm{C}$ for five days. The sclerotia that germinated at the end of the incubation period were considered to be alive and the diameter of mycelium were measured and recorded. For the control group, five sclerotia were placed in LB medium without bacterial isolates. Each treatment in the experiment had three replicates and the study was repeated twice. The effects of the antagonistic bacterial isolates on the survival rates and mycelium growth of sclerotia was determined and compared with the control group (Abdeljalil et al., 2016). 


\section{In vivo test}

According to the results obtain in the in vitro test, pot experiments were conducted using single, double and triple combinations of the three antagonistic bacteria isolates which had the highest effect on the pathogen. Dörtel F1 cucumber variety, which is sensitive to pathogen fungus, was used in the study which was conducted under controlled greenhouse conditions. Bacterial isolates that were streaked on King B media and incubated at $28{ }^{\circ} \mathrm{C}$ for $48 \mathrm{~h}$. Grown bacterial isolates were suspended in saline $(0.85 \% \mathrm{NaCl})$, and the density was adjusted to $10^{8}$ cells $/ \mathrm{ml}$ at $600 \mathrm{~nm}$ using spectrophotometer (PG Instrument T60U UV/VIS). Cucumber seedlings were dipped into the prepared suspension and left for $1 \mathrm{~h}$ for bacteria colonization and then planted in pots with sterile soil, peat and perlite (1:1:0.5). Seven days after the seedlings were transferred to the pots, a wound with a diameter of $5 \mathrm{~mm}$ was opened on the plant stem $4 \mathrm{~cm}$ above the soil, then $0.5 \mathrm{ml}\left(10^{8}\right.$ cells $\left./ \mathrm{ml}\right)$ bacterial suspension pipetted was on the wounds. Immediately afterwards, a 5-mm mycelium disc of S. sclerotiorum was placed on the opened wound. The inoculated spot was covered with moist cotton and wrapped with plastic film. Positive control group had plants inoculated only with S. sclerotiorum (Tozlu et al., 2016). In the negative control group, only water was applied to the plants, and for the chemical control group, Metalaxyl-M + Fludioxonil was applied to the plants at the dose recommended by the producer. Trial coincidence plots were set up two times with 10 replicates according to the trial pattern. Seven days after the application, dead and living plants in the control group and the treatments were counted.

\section{Statistical analyses}

The data obtained in the study were analyzed using variance analysis in SPSS statistics 25 package program and the differences between the means were determined with Duncan multiple comparison test at the $\mathrm{p} \leq 0.05$ significance level.

\section{Results}

\section{In vitro tests}

\section{Effects of antagonistic bacteria on the mycelial development of Sclerotinia sclerotiorum}

In in vitro studies, ten of the antagonistic bacteria isolates tested showed varying effects ranging between 65.49 and $88.25 \%$ on the pathogenic fungus, S. sclerotiorum. As can be seen in Table 2, it was determined that the effect of all bacterial isolates on the fungus were statistically significant compared to the control group. R-6 coded Pseudomonas thivervalensis isolate had the highest (88.25\%) effect on fungal pathogen (Fig. 2). All of the bacterial isolates tested had an inhibitory effect on the mycelium growth of the fungal pathogen greater than $60 \%$ (Table 2).

\section{The effect of antagonistic bacteria on the germination of Sclerotinia sclerotiorum} sclerotia

In this part of the study, the effect of the bacterial isolates on sclerotia viability was examined and according to the results, sclerotia treated with five isolates (R-1, R-2, R-4, $\mathrm{R}-5, \mathrm{R} 8)$ remained viable while the sclerotia treated with other five isolates (R-3, R-6, R7, R-9, R-10) were dead. Isolates which were highly efficacious on mycelium 
development were also effective on sclerotia. In addition, R2, R4 and R5 coded antagonists significantly suppressed mycelial growth of sclerotia that did not lose their viability. This situation reveals that these antagonists have fungistatic effects (Table 3).

Table 2. The effects of antagonistic bacteria on the mycelial development of Sclerotinia sclerotiorum

\begin{tabular}{c|c|c|c}
\hline Codes & Treatments & Diameter of mycelium $\mathbf{( m m )}$ & Average effect rate (\%) \\
\hline K & Control & $90 \mathrm{a}^{*}$ & $0 \mathrm{f}$ \\
R-1 & Pseudomonas kilonensis & $23.81 \mathrm{~cd}$ & $73.54 \mathrm{~cd}$ \\
R-2 & Pseudomonas monteilii & $13.46 \mathrm{ef}$ & $85.04 \mathrm{ab}$ \\
R-3 & Pseudomonas brassicacearum & $10.85 \mathrm{f}$ & $87.93 \mathrm{a}$ \\
R-4 & Pseudomonas thivervalensis & $12.40 \mathrm{ef}$ & $86.31 \mathrm{ab}$ \\
R-5 & Pseudomonas koreensis & $15.27 \mathrm{e}$ & $83.03 \mathrm{~b}$ \\
R-6 & Pseudomonas thivervalensis & $10.56 \mathrm{f}$ & $88.25 \mathrm{a}$ \\
R-7 & Pseudomonas chlororaphis & $14.71 \mathrm{ef}$ & $83.64 \mathrm{ab}$ \\
R-8 & Pseudomonas sp. & $31.05 \mathrm{~b}$ & $65.49 \mathrm{e}$ \\
R-9 & Pseudomonas sp. & $25.86 \mathrm{c}$ & $71.26 \mathrm{~d}$ \\
R-10 & Pseudomonas thivervalensis & $20.03 \mathrm{~d}$ & $77.73 \mathrm{c}$ \\
\hline
\end{tabular}

*The same letters next to averages in the same column indicate that difference between applications are not significant. (Duncan multiple comparison test, $\mathrm{p} \leq 0.05$ )

Table 3. The effect of antagonistic bacteria on Sclerotinia sclerotiorum sclerotia viability

\begin{tabular}{c|c|c|c}
\hline Codes & Treatments & Sclerotia viability & Diameter of mycelium (mm) \\
\hline K & Control & Viable & $60 \mathrm{a}^{*}$ \\
$\mathrm{R}-1$ & Pseudomonas kilonensis & Viable & $53.09 \mathrm{~b}$ \\
R-2 & Pseudomonas monteilii & Viable & $21.25 \mathrm{~d}$ \\
R-3 & Pseudomonas brassicacearum & Dead & $0 \mathrm{f}$ \\
R-4 & Pseudomonas thivervalensis & Viable & $14.27 \mathrm{e}$ \\
R-5 & Pseudomonas koreensis & Viable & $26.38 \mathrm{~cd}$ \\
R-6 & Pseudomonas thivervalensis & Dead & $0 \mathrm{f}$ \\
R-7 & Pseudomonas chlororaphis & Dead & $0 \mathrm{f}$ \\
R-8 & Pseudomonas sp. & Viable & $32.39 \mathrm{c}$ \\
R-9 & Pseudomonas sp. & Dead & $0 \mathrm{f}$ \\
R-10 & Pseudomonas thivervalensis & Dead & $0 \mathrm{f}$ \\
\hline
\end{tabular}

*The same letters next to averages in the same column indicate that difference between applications are not significant. (Duncan multiple comparison test, $\mathrm{p} \leq 0.05$ )

\section{In vivo test}

In vivo tests were conducted with three isolates (R-3, R-6 and R-7) which had the highest effects on the mycelial growth and sclerotia viability of S. sclerotiorum in the in vitro studies. Single, double and triple combinations of these three isolates were used. In the evaluation of the applications in the pot study conducted under greenhouse conditions, 
the dead/alive plants were counted. According to the results of the study, $100 \%$ death occurred in positive control where only the fungal pathogen was applied, whereas no plant death occurred in negative control and pesticide control applications. In R-3 single application and R-3 + R-6 + R-7 triple combination application, death (50\%) occurred in 5 out of 10 plants. In R-6 single application, and R-3 + R- 6 and R- $6+$ R-7 double combination applications, death occurred in 6 out of 10 plants (60\%). Among the applications, the highest effect was seen in R-7 single application (Fig. 3) and R-3 + R-7 double application. In both applications, while death occurred in 2 out of 10 plants, it was observed that 8 of them were alive and there were no signs of disease or death. It was found that the disease was suppressed by $80 \%$ in both applications (Table 4).

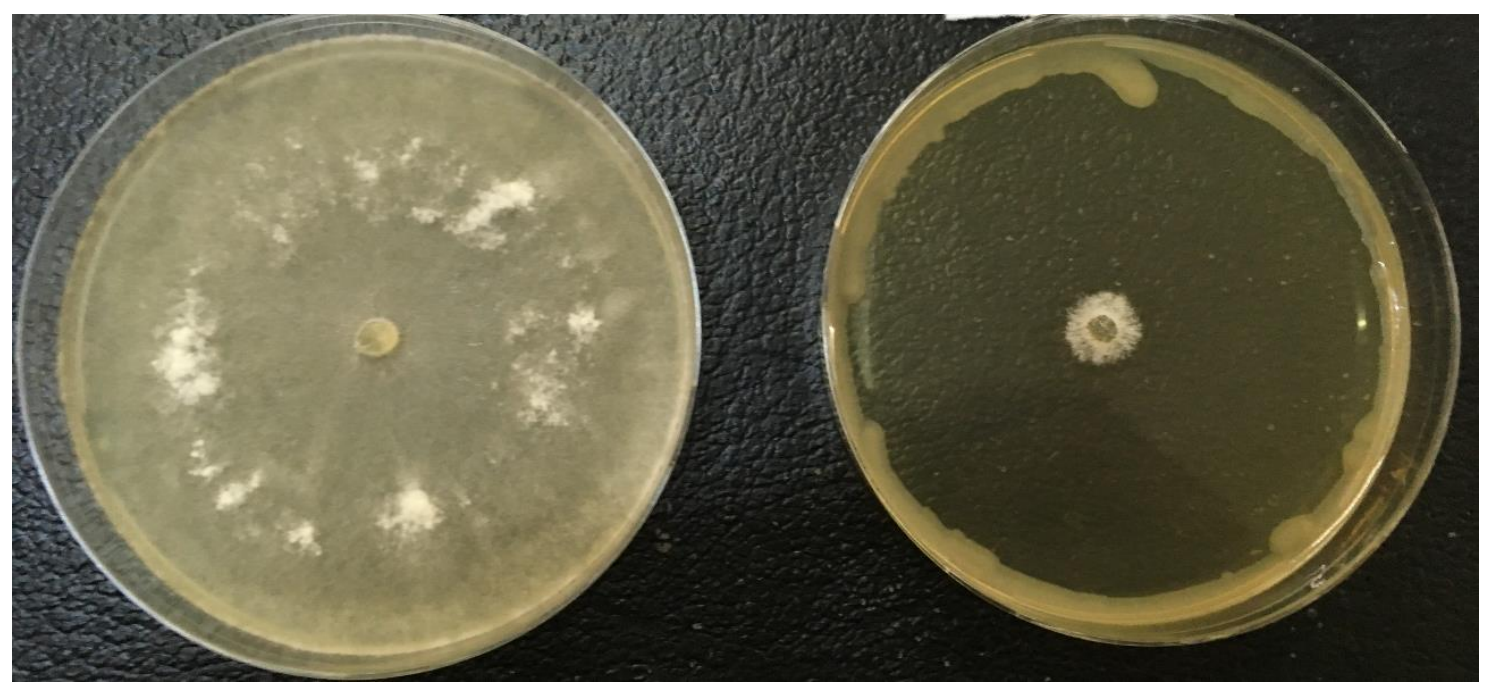

Figure 2. Effect of R-6 coded Pseudomonas thivervalensis isolate on the mycelial development of S. sclerotiorum

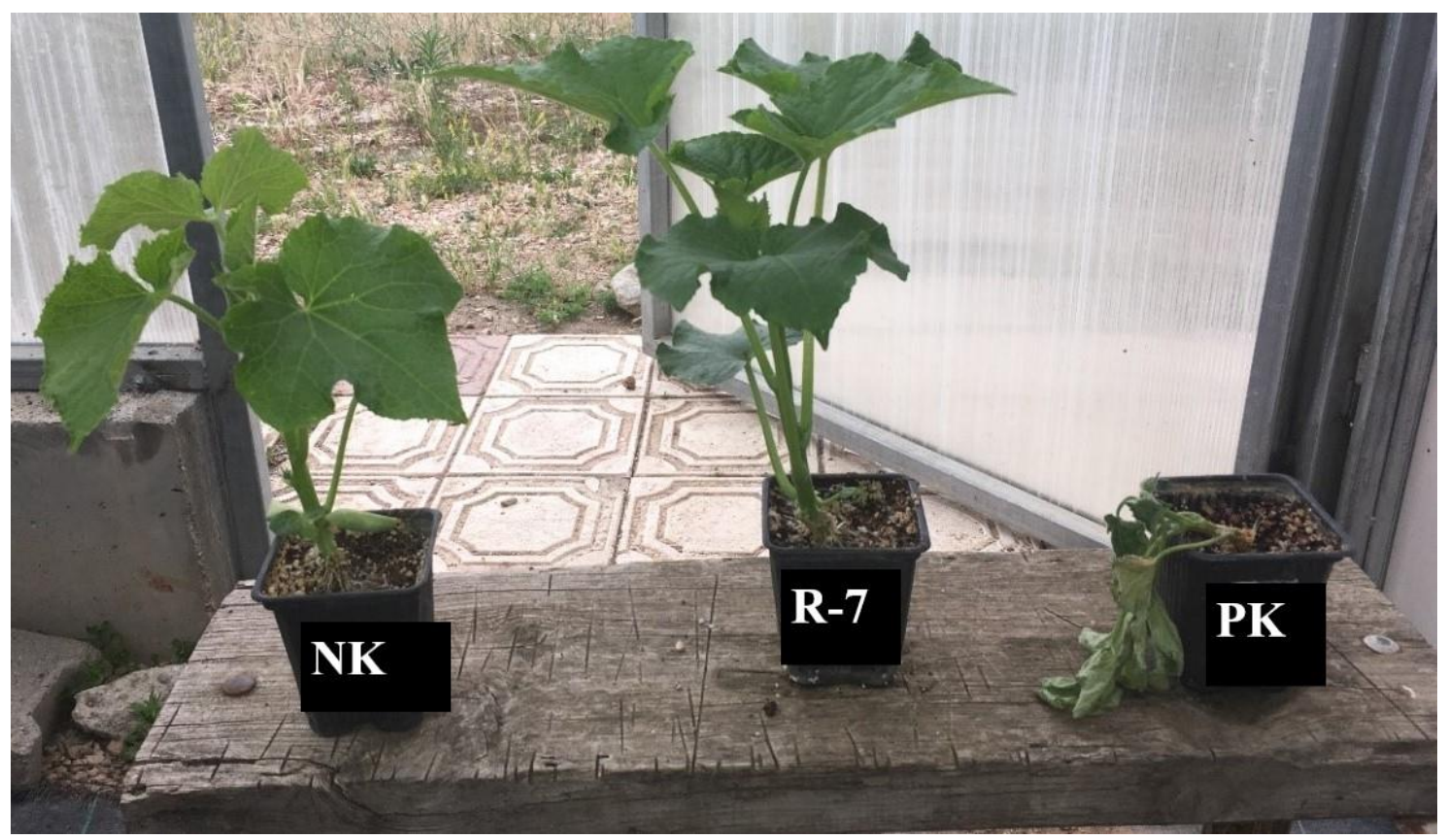

Figure 3. Differences in plant growth in NK, R-7 and PK treatments 
Table 4. The effect of antagonistic bacteria on white rot disease in cucumber plant

\begin{tabular}{|c|c|c|c|c|}
\hline Codes & Treatments & $\begin{array}{l}\text { Number of } \\
\text { dead plants }\end{array}$ & $\begin{array}{l}\text { Number of } \\
\text { live plants }\end{array}$ & $\begin{array}{l}\text { Inhibition } \\
\text { rate }(\%)\end{array}$ \\
\hline PK & Sclerotinia sclerotiorum treatment & 10 & 0 & 0 \\
\hline NK & Treatment with pure water & 0 & 10 & 100 \\
\hline IK & Metalaxyl-M + Fludioxonil & 0 & 10 & 100 \\
\hline $\mathrm{R}-3$ & Pseudomonas brassicacearum & 5 & 5 & 50 \\
\hline $\mathrm{R}-6$ & Pseudomonas thivervalensis & 6 & 4 & 40 \\
\hline $\mathrm{R}-7$ & Pseudomonas chlororaphis & 2 & 8 & 80 \\
\hline $\mathrm{R}-3+\mathrm{R}-6$ & $\begin{array}{c}\text { Pseudomonas brassicacearum }+ \\
\text { Pseudomonas thivervalensis }\end{array}$ & 6 & 4 & 40 \\
\hline $\mathrm{R}-3+\mathrm{R}-7$ & $\begin{array}{c}\text { Pseudomonas brassicacearum + } \\
\text { Pseudomonas chlororaphis }\end{array}$ & 2 & 8 & 80 \\
\hline $\mathrm{R}-6+\mathrm{R}-7$ & $\begin{array}{c}\text { Pseudomonas thivervalensis }+ \\
\text { Pseudomonas chlororaphis }\end{array}$ & 6 & 4 & 40 \\
\hline $\mathrm{R}-3+\mathrm{R}-6+\mathrm{R}-7$ & $\begin{array}{l}\text { Pseudomonas brassicacearum }+ \text { Pseudomonas } \\
\text { thivervalensis }+ \text { Pseudomonas chlororaphis }\end{array}$ & 5 & 5 & 50 \\
\hline
\end{tabular}

\section{Discussion}

Today, in order to increase the quality and yield in plant production and reduce the use of pesticides, the use of antagonistic bacteria against plant diseases and/or plant growth regulating rhizobacteria within the scope of biological control has been an important research topic. Studies with these bacteria show that they are promising in terms of suppressing plant diseases and ensuring healthy plant growth. Although cultural measures, physical and chemical control are used in the management of white mold disease, there are difficulties in managing the disease due to fungicide resistance problem and the survival of sclerotia for many years.

In this study, the effects of antagonistic bacteria which were obtained from the soil rhizosphere and have the high ability to dissolve phosphorus and reduce nitrogen, was determined on the white mold disease agent Sclerotinia sclerotiorum (Lib.) de Bary in vitro and in vivo conditions. Our in vitro studies, antagonistic bacteria isolates tested showed varying effects ranging between $65.49-88.25 \%$ on $S$. sclerotiorum. And, five bacterial isolates caused complete sclerotia viability loss for $S$. sclerotiorum. Numerous studies similar to our in vitro study have been carried out by various researchers. El-Kafrawy (2008) reported that Pseudomonas fluorescens had an antagonistic effect of $69.26 \%$ on the radial growth of $S$. sclerotiorum and showed a significant suppressive effect on formation of sclerotia. A study by Helmy (2016) established that Streptomyces sp., Pseudomonas fluorescens and Bacillus subtilis (Bs1) reduced mycelium growth of S. sclerotiorum by $72.2 \%, 68.0,62.22$ respectively. Soylu et al. (2005) examined the antagonistic potential of 113 bacterial isolates against $S$. sclerotiorum in dual petri dishes and reported that Pseudomonas spp. AFP104 isolate was $83.3 \%$ effective on fungal pathogen. Similarly, study conducted by Onaran and Yanar (2011) showed that 12 of the 23 tested isolates especially $P$. putida and $P$. fluorescens from the genus Pseudomonas, Paenibacillus macerans, and Bacillus pumilis were highly effective and caused sclerotia death.

In our pot studies, Pseudomonas chlororaphis (R-7) and Pseudomonas brassicacearum + Pseudomonas chlororaphis $(\mathrm{R}-3+\mathrm{R}-7)$ were the most effective against white mold disease. It was found that the disease was suppressed by $80 \%$ in both applications. Previous studies conducted on the biological control of white mold disease 
have determined that several antagonistic bacteria partially or completely inhibits this fungal agent. Similar to our study, Onaran and Yanar's (2011) study under greenhouse conditions showed that the bacterial isolates tested were effective at 43.20-89.22\% on white mold disease with Burkholderia cepecia being the most effective. Likewise, Helmy (2016) reported that dipping seedlings into bacterial suspensions of Bacillus subtilis, $B$. thuringiensis and Streptomyces sp. prevented the disease severity caused by fungal pathogen by $100 \%$ after one week. A greenhouse study determined that Bacillus subtilis and Pseudomonas fluorescens species prevented white mold disease by $95-100 \%$ and $85-$ $90 \%$, respectively when cucumber seedlings were planted in soils treated with these antagonistic bacteria (El-Kafrawy, 2008).

Besides cucumber plants, a study conducted under greenhouse and field conditions for the biological control of $S$. sclerotiorum in canola plant, showed that P. chlororaphis (PA23), Pseudomonas sp. (DF-41) significantly suppressed the disease compared to $B$. amyloliquefaciens (BS6) fungicide application. While the rate of stem mold in the canola plants varied between $20-75 \%$, this rate was $5.0-29.6 \%$ in $P$. chlororaphis application (Fernando et al., 2007). In addition, Savchuck and Fernando (2004) stressed that the application of $P$. chlororaphis and $P$. brassicacearum at a density of $10^{4}-10^{8} \mathrm{cfu} / \mathrm{ml}$ was highly effective on ascospore germination.

Antagonistic bacteria against $S$. sclerotiorum affect the systemic resistance of the host plant. Pseudomonas spp., produces numerous antimicrobial compounds such as pyoluteorin, pyrrolnitrin, phenazines, siderophores, cyanide, 2,4-diacetylphloroglucinol (Compant et al., 2005) and enzymes such as cellulose, chitinase, proteases, beta-glucanase (Hernandez-Leon et al., 2015). Similarly, bacterial isolates of Pseudomonas spp. DF200 and DF209 which inhibit $S$. sclerotiorum under in vitro conditions produce benzothiazole, cyclohexanol, n-decanal, dimethyl trisulfide, 2-ethyl 1-hexanol, nonanal antifungal organic volatile compounds. In the field, bacteria prevent carpogenic germination of sclerotia and emergence of ascospores (Fernando et al., 2004). It has been reported that Pseudomonas brassicacearum, used in the present study, uses hydrogen cyanide $(\mathrm{HCN})$, protease, alginate, sclerocin and lipopeptide molecules, 2,4-diacetylphloroglucinol and antifungal compounds such as cyanide in suppressing S. sclerotiorum (Berry et al., 2010, 2014; Ortet et al., 2011; Loewen et al., 2014).

Pseudomonas chlororaphis, also used in this study, is an important biocontrol agent that suppresses $S$. sclerotiorum by producing antibiotics such as phenazine-1-carboxylic acid,2hydroxyphenazine and pyrrolnitrin (PRN) which causes hyphal lysis, vacuolation and protoplast leakage, hereby preventing sclerotia and spore germination (Savchuck, 2002; Fernando et al., 2007; Zhang et al., 2004a, b; Selin et al., 2010).

\section{Conclusion}

In recent years, negatives effects of pesticides used extensively in agricultural areas on both the environment and human health have been reported in many studies. Antagonistic bacteria or plant growth promoting rhizobacteria have the potential to protect against soilborne pathogens. Biopreparat or biofertilizers made from such microorganisms can be widely used in areas where sustainable organic agriculture. Our study revealed that antagonistic bacterial isolates have the potential to be used as a biological control agent against white rot disease. In this context, the efficacy of the R-7 coded isolate and the R$3+$ R-7 coded double combination, which were effective on the agent in both the in vitro and in vivo studies, should also be evaluated under greenhouse and field conditions. 
Acknowledgements. This study was extracted from the first author's master's thesis and was supported by the Tokat Gaziosmanpasa University Scientific Research Projects with the project no 2019/24 in Turkey.

\section{REFERENCES}

[1] Abdeljalil, N. O. B., Vallance, S., Gerbore, J., Rey, P., Daami-Remadi, M. (2016): Biosuppression of Sclerotinia stem rot of tomato and biostimulation of plant growth using tomato-associated rhizobacteria. - Journal of Plant Pathology and Microbiology 7(2): 331.

[2] Adams, P. B. (1990): The potential of mycoparasites for biological control of plant diseases. - Annual Review of Phytopathology 28: 59-72.

[3] Adams, P. B., Ayers, W. A. (1979): Ecology of Sclerotinia Species. - Phytopathology 69: 896-899.

[4] Aeron, A., Dubey, R. C., Maheshwari, D. K., Pandey, P., Bajpai, V. K., Kang, S. C. (2011): Multifarious activity of bioformulated Pseudomonas fluorescens PS1 and biocontrol of Sclerotinia sclerotiorum in Indian rapeseed (Brassica campestris L.). - Eur. J. Plant Pathology 131(1): 81-93.

[5] Agrios, G. N. (1997): Plant Pathology. - Academic Press, California.

[6] Aksay, A., Bicici, M., Cinar, O. (1991): Determination of Antagonists against Sclerotinia sclerotiorum (Lib) De Bary Causal Agent White Mold Disease. - Cukurova University Journal of Agricultural Faculty 6(2): 55-62.

[7] AL-Masri, M. I., Ali-Shtayeh, M. S., Elad, Y., Sharon, A., Tudzynski, P., Barakat, R. (2002): Effect of plant growth regulators on white mold (Sclerotinia sclerotiorum) on bean and cucumber. - Journal Phytopathology 150: 481-487.

[8] Anonymous (2008): Agricultural Control, Plant Health. - Republic of Turkey Ministry of Agriculture and Forestry, Ankara, pp. 73-77.

[9] Berry, C., Fernando, W. G. D., Loewen, P. C., de Kievit, T. R. (2010): Lipopeptides are essential for Pseudomonas sp. DF41 biocontrol of Sclerotinia sclerotiorum. - Canadian Journal of Plant Pathology 16: 93-108.

[10] Berry, C., Nandi, M., Manuel, J., Brassinga, A. K. C., Fernando, W. G. D., Loewen, P. C., de Kievit, T. R. (2014): Characterization of the Pseudomonas sp. DF41 quorum sensing locus and its role in fungal antagonism. - Biological Control 69: 82-89. http://dx.doi.org/10.1016/j.biocontrol.2013.11.005.

[11] Bogdanova, V. N., Karadzhova, L. V., Klimenko, T. F. (1986): Use of Coniothyrum minitans Cambell as a hyperparasite in controlling the pathogen of white rot of sunflower. - Sel's Kokhozyaistvennaya Biologia 5: 80-84.

[12] Budge, S. P., McQuilken, M. P., Fenlon, J. S., Whipps, J. M. (1995): Use of Coniothyrium minitans and Gliocladium virens for biological control of Sclerotinia sclerotiorum in glasshouse lettuce. - Biological Control 5: 513-522.

[13] Cinar, A., Bicici, M. (1982): Etiology and importance of head rot and root collar and stem blight diseases in sunflower plots in Cukurova. - III. Turkey Phytopathology Congress (12-15 October 1982) Adana, pp. 68-79.

[14] Compant, S., Duffy, B., Nowak, J., Christophe, C., Ait Barka, E. (2005): Use of plant growth-promoting bacteria for biocontrol of plant diseases: principles, mechanisms of action, and future prospects. - Applied and Environmental Microbiology 71(9): 49514959.

[15] Elkafrawy, A. (2008): biological control of white rot of cucumber caused by Sclerotinia sclerotiorum under greenhouse conditions. - Journal of Agricultural Research 6(1).

[16] Expert, J. M., Digat, B. (1995): Biocontrol of Sclerotinia wilt of sunflower by Pseudomanas fluorescens and Pseudomonas putida strains. - Canadian Journal of Microbiology 41: 685-691. 
[17] Fernando, W. G. D., Nakkeeran, S., Zhang, Y. (2004): Ecofriendly methods in combating Sclerotinia sclerotiorum (Lib.) de Bary. - Recent Res. Devel. Environ. Biol. 1: 329-347.

[18] Fernando, W. G. D., Nakkeeran, S., Zhang, Y., Savchuk, S. (2007): Biological control of Sclerotinia sclerotiorum (Lib.) de Bary by Pseudomonas and Bacillus species on canola petals. - Crop Protection 26: 100-107.

[19] Ferreira, S. A., Boley, R. A. (2002): Sclerotinia sclerotiorum. http://www.extento.hawaii.edu/kbase/Crop/Type/s_scler.htm (01.09.2018).

[20] Gerlagh, M., Goossen-van de Geijn, H. M., Fokkema, N. J., Vereijken, P. F. (1999): Long-term biosanitation by application of Coniotyhrium minitans on Sclerotinia sclerotiorum-infected crops. - Phytopathology 89(2): 141-147.

[21] Helmy, K. G. (2016): Screening potential of some bacterial species and Trichoderma harzianum against Sclerotinia sclerotiorum on cucumber. - Journal of Plant Protection and Pathology 7(12): 867-872.

[22] Hernandez-Leon, R., Rojas-Solis, D., Contreras-Perez. M., Orozco-Mosqueda, M. C., Macias-Rodriguez, L. L., Reyes-de la Cruz, H., Valencia-Cantero, E., Santoyo, G. (2015): Characterization of the antifungal and plant growth-promoting effects of diffusible and volatile organic compounds produced by Pseudomonas fluorescens strains. - Biological Control 81: 83-92.

[23] Imriz, G., Ozdemir, F., Topal, I., Ercan, B., Tas, M. N., Yakısır, E., Okur, O. (2014): Plant growth promoting rhizobacteria and effect mechanisms of PGPR in plant production. - Electronic Microbiology Journal TR. 12: 1-19.

[24] Inbar, J., Menendez, A., Chet, I. (1996): Hyphal Interaction between Trichoderma harzianum and Sclerotinia sclerotiorum and its role in biological control. - Soil Biology and Biochemistry 28(6): 757-763.

[25] Kamal, M. M., Lindbeck, K. D., Savocchia, S., Ash, G. J. (2015): Biological control of sclerotinia stem rot of canola using antagonistic bacteria. - Plant Pathology 64: 13751384.

[26] Kamensky, M., Ovadis, M., Chet, I., Chernin, L. (2003): Soil-borne strain IC14 of Serratia plymuthica with multiple mechanisms of antifungal activity provides Biocontrol of Botrytis cinerea and Sclerotinia sclerotiorum diseases. - Soil Biology and Biochemistry 35: 323-331.

[27] Kotan, R. (2017): Oral presentation. $-6^{\text {th }}$ Entomopathogens and Microbial Control Congress, 14-16 September 2017, Gaziosmanpasa University, Tokat, Turkey.

[28] Kurt, S., Uysal, A., Kara, M., Soylu, S., Soylu, E. M. (2017): Natural infection of potato by Sclerotinia sclerotiorum causing stem rot disease in Turkey. - Australasian Plant Disease Notes 12: 39.

[29] Loewen, P. C., Switala, J., Fernando, W. G. D., de Kievit, T. (2014): Genome sequence of Pseudomonas brassicacearum DF41. - Genome Announcements 2(3): e00390-14: 1-2.

[30] Mansour, T. A., Nida, Y. A., Patrice, S. (2008): Biological control of Sclerotinia sclerotiorum (Lib.) de Bary with Trichoderma harzianum and Bacillus amyloliquefaciens. - Crop Protection 27: 1354-1359.

[31] McLaren, D. L., Huang, H. C., Rimmer, S. R. (1996): Control of apothecial production of Sclerotinia sclerotiorum by Coniothyrium minitans and Talaromyces flavus. - Plant Disease 80: 1373-1378.

[32] Mehta, N., Hieu, N., Sangwan, M. (2012): Efficacy of various antagonistic isolates and species of against causing white stem rot of mustard. - Journal of Mycology and Plant Pathology 42(2): 244-250.

[33] Mun, B-G., Lee, W-H, Kang, S-M, Lee, S-U, Lee, S-M., Lee, D-Y, Shahid, M., Yun, BW, Lee, I-J. (2019): Streptomyces sp. LH4 promotes plant growth and resistance against Sclerotinia sclerotiorum in cucumber via modulation of enzymatic and defense pathways. - Plant Soil. https://doi.org/10.1007/s11104-019-0441-4.

[34] Onaran, A. (2009): Study on the identification, distribution, mycelial compatibility groups pathogenicity and biological control of Sclerotinia sclerotiorum (Lib.) de Bary 
(white mold disease of greenhouse grown cucumber) in Antalya Province. - Ph. D. Thesis, Gaziosmanpasa University, Graduate School, Tokat, Turkey.

[35] Onaran, A., Yanar, Y. (2004): Studies on the prevalence of the white rot agent Sclerotinia sclerotiorum (Lib.) de Bary in cucumbers in greenhouses in Tokat and Amasya and determination of Mycelium compatibility groups. - Turkey II. Plant Protection Congress, 27-29 August 2007, Isparta.

[36] Onaran, A., Yanar, Y. (2011): Screening bacterial species for antagonistic activities against the Sclerotinia sclerotiorum (Lib.) de Bary causal agent of cucumber white mold disease. - African Journal of Biotechnology 10(12): 2223-2229.

[37] Ortet, P., Brakat, M., Lalaouna, D., Fochesato, S., Barbe, V., Vacheria, B., Santaella, C., Heulin, T., Achouak, W. (2011): Complete genome sequence of a beneficial plant rootassociated bacterium Pseudomonas brassicacearum. - Journal of Bacteriology 193: 3146-3147.

[38] Peter, C., Loewen, J. S., Fernando, W. G. D., de Kievit, T. R. (2014): Genome sequence of Pseudomonas brassicacearum DF41. - Genome Announcements 2-3: e00390-14. DOI: $10.1128 /$ genomeA.00390-14.

[39] Phillips, A. (1986): Factors affecting the parasitic activity of Gliocladium virens on sclerotia of Sclerotinia sclerotiorum and a note on its host range. - Journal Phytopathology 116(3): 212-220.

[40] Rostami, S., Maleki, M., Shahriari, D. (2013): The Use of Bacillus amyloliquefaciens to Control of Sclerotinia Stem Rot (Sclerotinia sclerotiorum) of Cucumber. - International Journal of Farming and Allied Sciences 2(22): 965-970.

[41] Saharan, G. S., Mehta, N. (2008): Sclerotinia Diseases of Crop Plants: Biology, Ecology and Disease Management. - Springer, Dordrecht.

[42] Savchuk, S. C. (2002): Evaluation of biological control of Sclerotinia sclerotiorum on Canola (Brassica napus) in the lab, in the greenhouse, and in the field. - Msc. Thesis, University of Manitoba, pp. 49-83.

[43] Savchuk, S., Fernando, W. G. D. (2004): Effect of timing of application and population dynamics on the degree of biological control of Sclerotinia sclerotiorum by bacterial antagonists. - FEMS Microbiology Ecology 49: 379-388.

[44] Selin, C., Habibiban, R., Poritsanos, N., Athukorala, S. N. P., Fernando, D., de Kievit, T. R. (2010): Phenasines are not essential for Pseudomonas chlororaphis PA23 Biocontrol of Sclerotinia sclerotiorum, but do play a role in biofilm formation. - FEMS Microbiology Ecology 71: 73-83.

[45] Soylu, S., Soylu, E. M., Kurt, Ş., Ekici, Ö. K. (2005): Antagonistic potentials of rhizosphere associated bacterial isolated against soil borne diseases of tomato and pepper caused by Sclerotinia sclerotiorum and Rhizoctonia solani. - Pakistan Journal of Biological Sciences 8(1): 43-48.

[46] Srinivasan, A., Kang, I., Singh, R., Kaur, J. (2001): Evaluation of selected Trichoderma isolates against Sclerotinia sclerotiorum causing white rot of Brassica napus L. - Proc XI International Sclerotinia Workshop, York, UK, pp. 143-144.

[47] Sun, G., Yao, T., Feng, C., Chen, L., Li, J., Wang, L. (2017): Identification and biocontrol potential of antagonistic bacteria strains against Sclerotinia sclerotiorum and their growth-promoting effects on Brassica napus. - Biological Control 104: 35-43.

[48] Thaning, C., Welch, C. J., Borowicz, J. J., Hedman, R., Gerhardson, B. (2001): Suppression of Sclerotinia sclerotiorum apothecial formation by the soil bacterium Serratia plymuthica identification of a chlorinated macrolide as one of the causal agents. - Soil Biology and Biochemistry 33(12-13): 1817-1826.

[49] Tok, F. M., Kurt, S. (2007): Characterization by pathogenicity methods and mycelium compatibility (MUG) of Sclerotinia sclerotiorum (Lib.) De Bary isolates obtained from the Mediterranean region greenhouse tomato plants. - Turkey Plant Protection Congress (27-29 August 2007), Isparta. 
[50] Tozlu, E., Demirci, E. (2008): Incidence and characterization of sunflower stem rot disease caused by Sclerotinia sclerotiorum and S. minor in Pasinler Plain of Erzurum, and reaction of some sunflower cultivars to the pathogens. - Plant Protection Bulletin 48(4): 19-33.

[51] Tozlu, E., Demirci, E. (2011): Determination of potential biocontrol organisms against Sclerotinia sclerotiorum and S. minor on sunflower. - Anadolu Journal Agricultural Science 26(2): 101-106.

[52] Tozlu, E., Parisa, M., Kotan, M. S., Nadaroglu, H., Kotan, R. (2016): Biological control of Sclerotinia sclerotiorum (Lib.) de Bary, the causal agent of white mould disease in red cabbage, by some bacteria. - Plant Protection Science 52(3): 188-198.

[53] Tuncer, F. E., Damdere, H. (1997): Research on the biological control possibilities of the disease of white rot (Sclerotinia sclerotiorum (Lib.) De Bary) damaging vegetables in the greenhouses of Antalya Province (final report). http://www.tagem.gov.tr/projeler/97/bsag/bsagl8.html.

[54] Turhan, G., Grossamann, F. (1986): Investigation of a great number of actinomycete isolates on their antagonistic effects against soil-borne fungal plant pathogens by an improved method. - Journal of Phytopathology 116(3): 193-288.

[55] Türk, M. F., Doğu, M. (2004): Determination of disease incidence and mycelial compatible groups of Sclerotinia sclerotiorum in lettuce growing in greenhouses of Canakkale Province. - MKU Journal of Agricultural Faculty 9(1-2): 1-8.

[56] Whipps, J. M., Budge, S. (1990): Screening for sclerotial mycoparasites of Sclerotinia sclerotiorum. - Mycological Research 94(5): 607-612.

[57] Whipps, J. M., Gerlagh, M. (1992): Biology of Coniothyrium minitans and its potential for use in disease biocontrol. - Mycological Research 96: 897-907.

[58] Whipps, J. M., Sreenivasaprasad, S., Muthumeenakshi, S., Rogers, C. W., Challen, M. P. (2008): Use of Coniothyrium minitans as a biocontrol agent and some molecular aspects of sclerotial mycoparasitism. - European Journal Plant Pathology 121: 323-330.

[59] Yildı, M. (1970): Studies on Sclerotina Species, their taxonomy, distribution, degree of damage and pathogenicity in Izmir, Manisa and Aydin Provinces. - Ege University, Journal Agricultural Faculty Serial A 1: 223-235.

[60] Yücer, M. (1980): Studies on The Rate of Diseases, Fungal Factors and Pathogenicity of Sunflowers in the Thrace Region. - İstanbul Province Plant Protection Central Research Enstitute, Serial 14, Ankara.

[61] Zazzerini, A., Tosi, L. (1985): Observations on the antagonistic activity of some fungi and bacteria against Sclerotinia sclerotiorum (Lib.) de Bary. - Difesa-delepiante 8(2): 163-168.

[62] Zazzerini, A., Tosi, L., Rossi, S. (1987): Antagonistic effect of Bacillus spp. on Sclerotinia sclerotiorum Sclerotia. - Phytopathologia Mediterranea 26: 185-187.

[63] Zhang, Y. (2004a): Biocontrol of Sclerotinia stem rot of canola by bacterial antagonists and study of biocontrol mechanisms involved. - Msc. Thesis, University Manitoba, Winnipeg.

[64] Zhang, Y., Fernando, W. G. D., Kavitha, K., Nakkeeran, S., Ramarathnam, R. (2004b): Combination of mechanisms in Pseudomonas chlororaphis strain PA-23 results in control of multiple pathogens. - Phytopathology 94: 115. 